\title{
Preservation of Bone Tissue of Human Remains from Jomon Sites
}

\author{
Yasuo FukUSHIMA \\ Department of Anthropology, The University of Tokyo
}

\begin{abstract}
Thin sections for the microscopic observation were made of human remains from five Jomon sites ; Miyakojima, Ebishima, Ubayama, Ikawazu and Yosekura. These sites except Yosekura which is a cave site of limestone, are shell mounds. The bone pieces considered as a part of long bone were embedded in Metacrylate and Polyester, and were sliced about $500 \mu$ thick and ground off $100 \mu$ thick or thinner. Some of these sections were stained by Hematoxylin and Eosin. Bone tissues of these samples are destroyed greatly. The best preserved samples are from Ubayama, but their lamellar structures are destroyed. On the samples from Ikawazu, only traces of Haversian or Volkmann's canals can be found and even the polarization microscope scarcely shows collagen fibers. Burned bone from Yosekura has better preserved lamellar structures than the unburned one, but collagen fiber is not well preserved.
\end{abstract}

\section{INTRODUCTION}

Considerable observations have been carried out on human remains from many Jomon sites, however, these observations are mostly limited within the macrostructure of bone. It is partly due to the difficulty of making thin sections of fossil bones for microscopic observations because of the destruction of tissue. About the bone tissue of fossil human bones (Michä̈LIS, 1930) and Neanderthal (Ascenzi, 1955 ; Sergi et al., 1972) only a few reports were available.

Therefore, this report aims to elucidate how the tissue of Jomon period is preserved.

\section{MATERIALS AND METHODS}

Materials used are separated bone pieces collected from human remains in five
Jomon sites ; Ebishima, Miyakojima, Ubayama, Ikawazu and Yosekura (Fig. 1), and kept in the University Museum of the University of Tokyo. All sites except Yosekura are shell mounds, while Yosekura is the cave site of limestone. These remains are regarded as of prehistoric hunters and gatherers. The bone pieces are considered as parts of some long bones but their correct origins are not clear. Ground thin sections were made from these bone pieces as follows; they were dehydrated in the series of alcohol and embedded in metacrylate (Oken). From these plastic blocks the bone pieces covered with thin plasitc layer were cut out, becouse metacrylate is too sticky to slice off. Then they were embedded again in polyester (Marumoto) after the orientation along the long axis of bone. These polyester blocks were sliced into about 


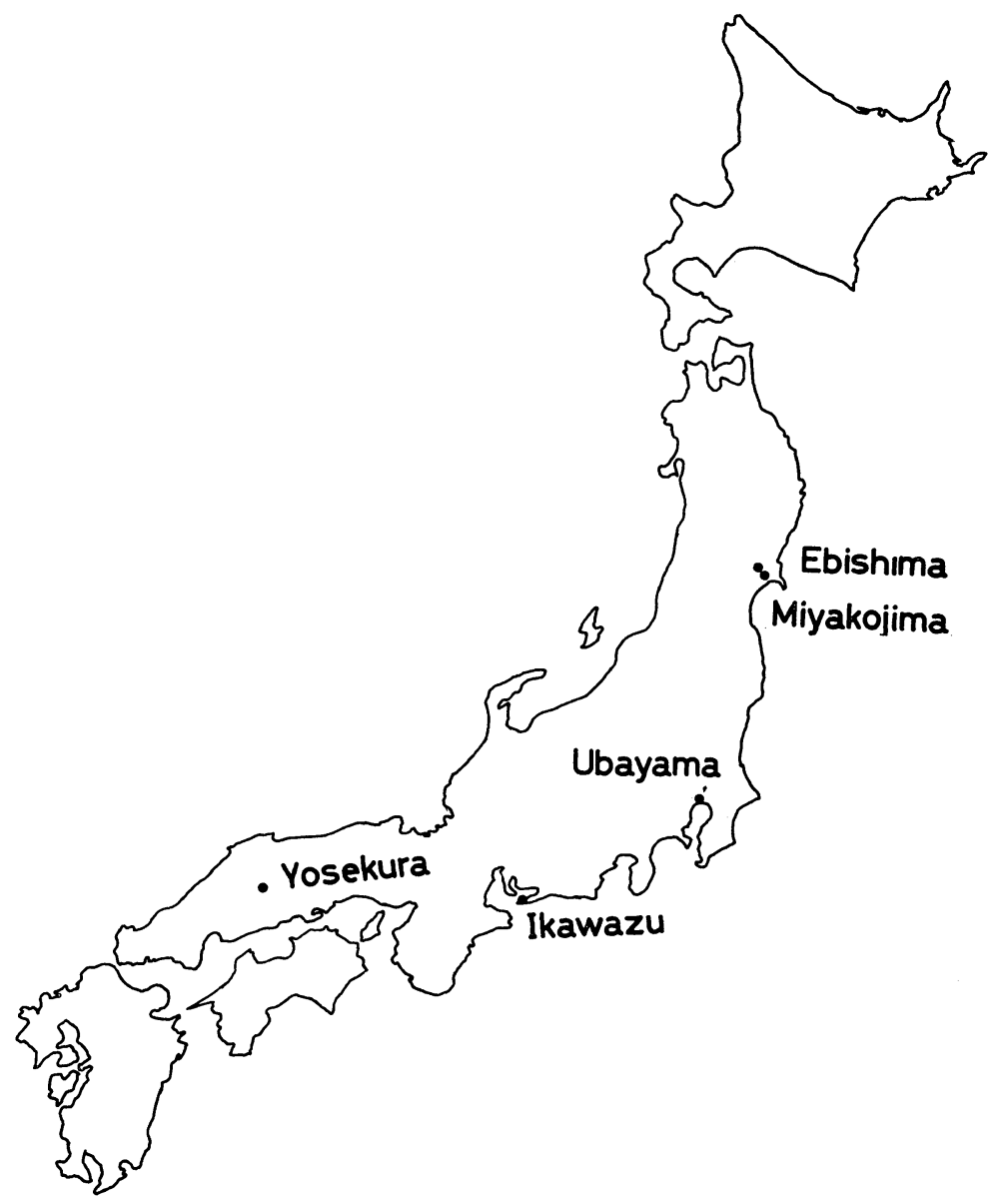

Fig. 1. Location of 5 Jomon Sites.

$500 \mu$ thick sections by the rotary cutting lar structures; Haversian systems, intermachine with carborundum wheel. These stitial lamellae and circumferential lamelsections were further ground off about lae (BLOOM and FAWCETT, 1968). $100 \mu$ thick or thinner. Some of these thin sections were stained by Hematoxylin and Eosin. These sections were examined under the microscope, and to detect the preserved collagen fiber more clearly the polarization microscope was used.

\section{RESULT}

The tissue of human compact bone consists mainly of the following three lamel-

On the bone tissue from Miyakojima, Haversian and Volkmann's canals can be observed (Figs. 2-1, 2-2). Some Haversian systems are well preserved, while the others are destroyed. The lamellar structure of interstitial lamellae is preserved at some parts. In these preserved lamellae even some osteocyte lacunae are observable. In one of the bone pieces from this site the tissue was almost completely de- 
stroyed.

Bone tissue from Ebishima is mostly destroyed (Figs. 3-1, 3-2). All Haversian systems are broken, while the interstitial lamellae are preserved in some parts, but lamellar structure is not observed under the ordinary microscope.

On bone tissue from Ubayama, most of Haversian canals are preserved (Figs. 4-1, 4-2, 5-1, 5-2). At preserved Haversian systems osteocyte lacunae can be found. Some Haversian systems are destroyed. The interstitial lamellae are almost completely destroyed. But even in the destroyed lamellae, some lacunae are found.

Bone tissue from Ikawazu has only traces of Haversian and Volkmann's canals (Figs. 6-1, 6-2). Interstitial lamellae and lamellae of Haversian systems are not found at all under the ordinary microscope. But polarization microscope exhibits some lamellae of Haversian systems, but no lacunae are present.

Bone tissue from Yosekura is greatly destroyed, but the tissue of burned piece is well preserved (Figs. 7-1, 7-2). On burned sample, Haversian systems are relatively well preserved, but interstitial lamellae are almost destroyed. At a wellburned part some osteocyte lacunae are found.

Therefore any bone pieces from Jomon sites don't show completely preserved microstructure. But conditions of preservation differ greatly according to the parts even in the same preparation. The best preserved bone tissue seems to be from Ubayama. In burned bone the tissue may be well preserved, but collagen fibers are not always preserved well. The preservation of lamellar structure may not necessarily correspond to the preservation of collagen fiber, that is, sometimes collagen fiber cannot be detected on the samples with well preserved lamellar structure.

\section{DISCUSSION}

To make preparations from fossil bones, decalcifing method was used as well as Araldite embedding method (AscenzI, 1955; Sergi et al., 1972). But for bone pieces from Jomon sites decalcifing method was not successful, probably because of the destruction of collagen fiber of bone. Comparing with Araldyte, Metacrylate is more permeable and does not give any great damage on staining.

On many of these sections, both preserved and destroyed Haversian systems are found at a preparation. It may indicate that the destruction of bone tissue begins from the surrounding of Haversian or Volkmann's canal and advances into the interstitial lamellae, then further into the remained Haversian systems. The destruction seems to be the disappearance of lamellar structure and collagen fibers coupled with the substitution of mineral. It is not clear what mineral invades and how it does. But the mineral may be some potassium complex, because the bone piece is not endurable against decalcifying. And the lamellar structure under the ordinary light does not always mean the remaining of collagen fiber, because some lamellar structures are not birefringent under the polarized light. 


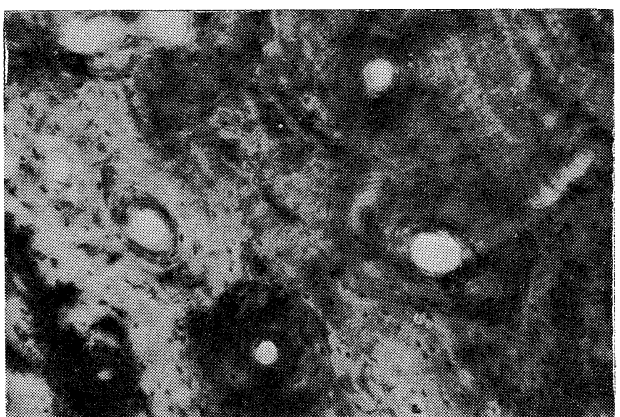

Fig. 2-1. Bone tissue from Miyakojima under the ordinary light. ( $x$ 100)

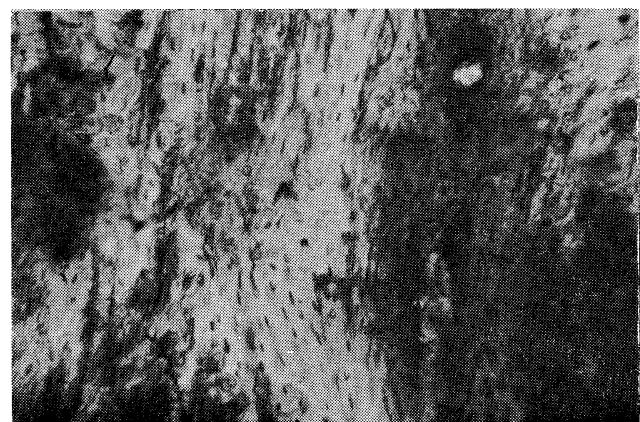

Fig. 3-1. Bone tissue from Ebishima under the ordinary light. (x 100)

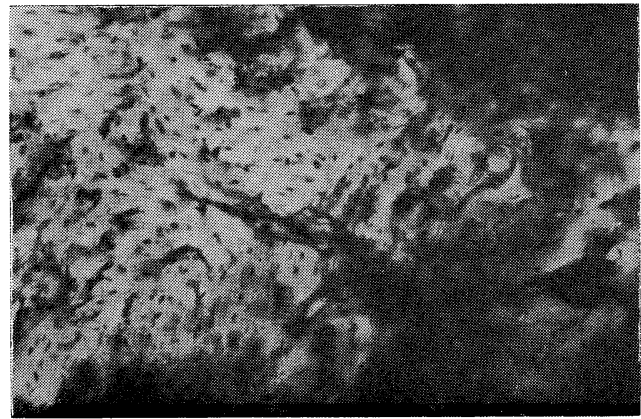

Fig. 4-1. Bone tissue from Ubayama under the ordinary light. ( $x$ 100)

The two factors, which cause the destruction of bone tissue, can be suggested. One is the time and another is the condition of surroundings. The shellmounds are said to avail good preservation of bony substances (WATANABE, 1950a), but among

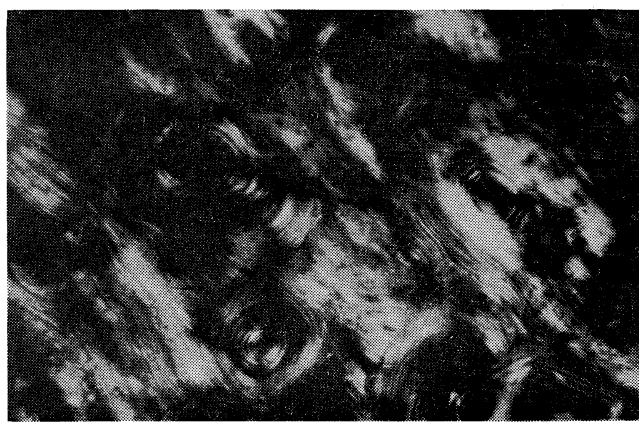

Fig. 2-2. Bone tissue from Miyakojima under the polarized light. (x 100)

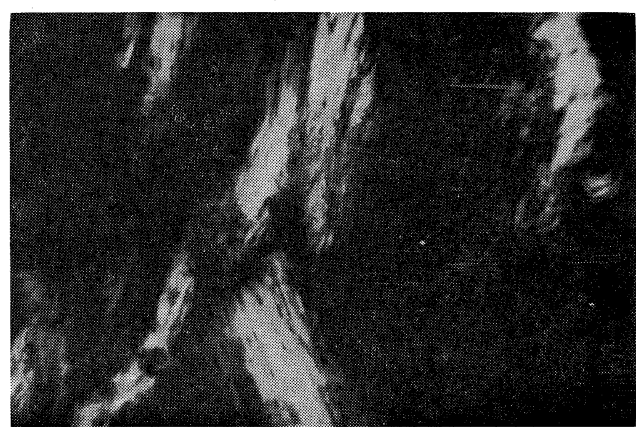

Fig. 3-2. Bone tissue from Ebishima under the polarized light. (x 100)

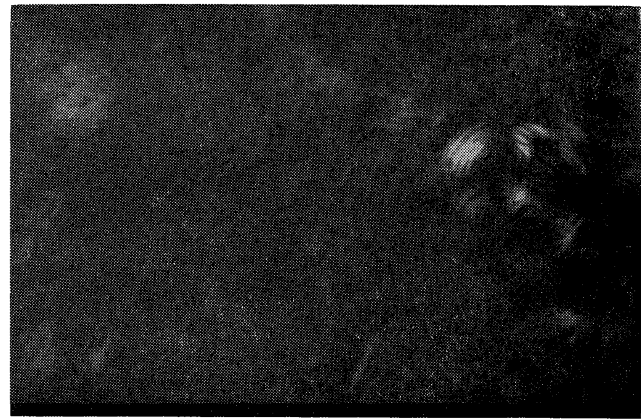

Fig. 4-2. Bone tissue from Ubayama under the polarized light. ( $x$ 100)

shellmounds the condition of preservation of bone tissue is various. It may be temperature, gound water or microorganism which causes this variety. The four stages of fossilization of bone were suggested that the first stage was recrystallization along 


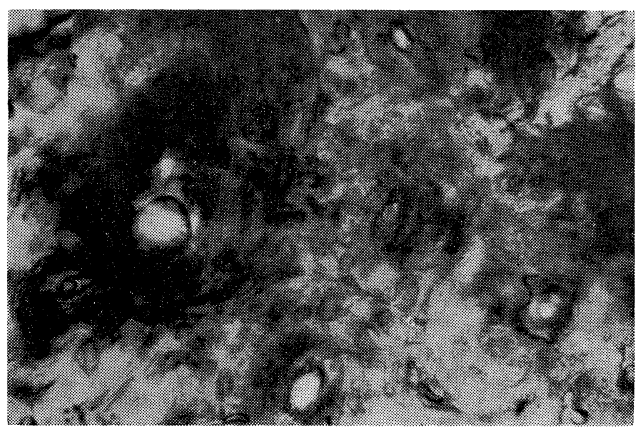

Fig. 5-1. Bone tissue from Ubayama under the ordinary light. ( $x$ 100)

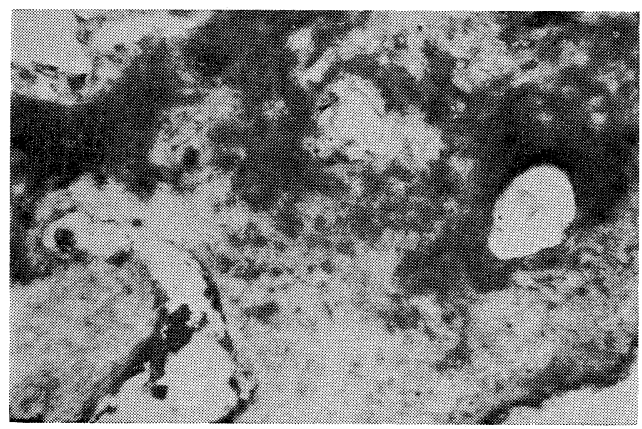

Fig. 6-1. Bone tissue from Ikawazu under the ordinary light. (x 100)

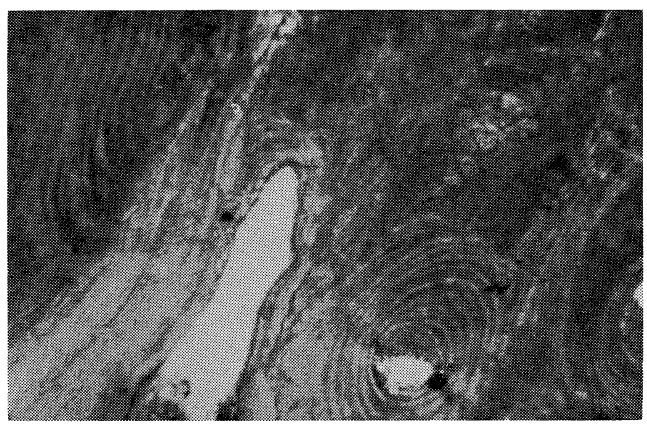

Fig. 7-1. Bone tissue from Ikawazu under the ordinary light. ( $x$ 100)

fracture lines only, the second was a bone margin recrystallization, the third was a filling of the Haversian canal system, and the fourth was complete destruction of most of the Haversian elements except the central canals (PAINe, 1937). But this

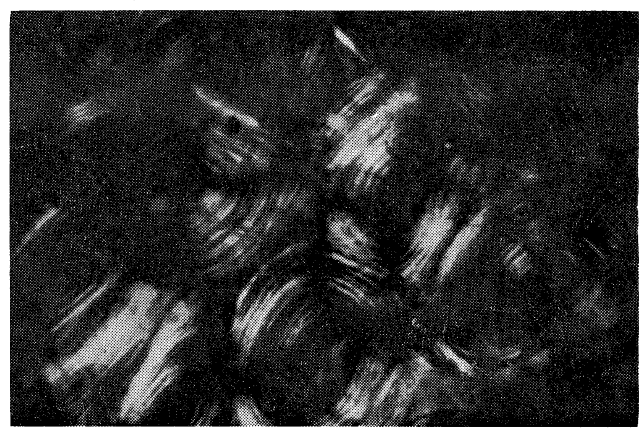

Fig. 5-2. Bone tissue from .Ubayama under the polarized light. ( $x$ 100)

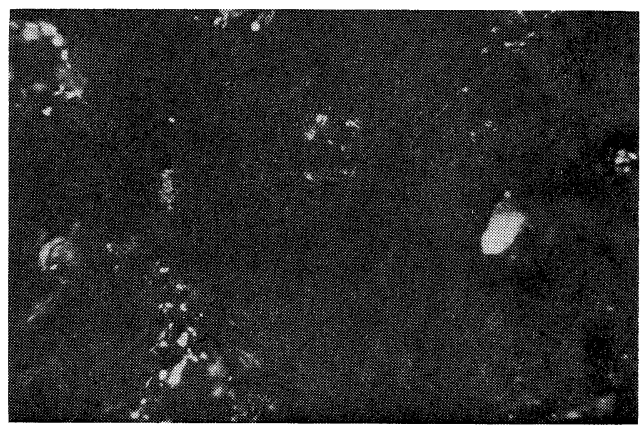

Fig. 6-2. Bone tissue from Ikawazu under the polarized light. ( $x$ 100)

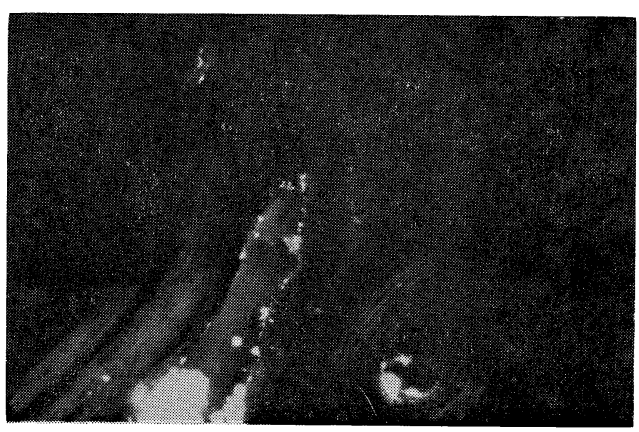

Fig. 7-2. Bone tissue from Ikawazu under polarized. light. (x 100)

process may be set for the very long-term cases, and no remains from Jomon sites seems to be always destroyed according to this process. The Haversian or Volkmann's canals seem to be very persistent against the destruction and they can be found at 
the last stage of destruction (PAINE, 1937; Faculty of Medicine, the University of WATANABE, 1950b).

Tokyo for the assistances to make thin

This preservation of bone tissue may show the general condition of human remains of these sites, because these observations were made at the best preserved part of the bone pieces.

\section{SUMMARY}

Thin sections were made from plastic embedded human bone pieces from five Jomon sites. And these were examined under the ordinary and polarization microscope. The bone tissue of these human remains is not preserved well. Conditions of preservation are very different in each site. But even the best preserved one from Ubayama contains some destroyed Havarsian systems and some mineral invades into the destroyed parts. In many cases, the destruction advances into the interstitial lamellae and osteocyte lacunae are also disappeared.

\section{ACKNOWLEDGMENT}

The author is indebted to Dr. B. Endo for the preparation of materials and for the useful suggestions and assistances, and to doctors of Department of Oral Surgery, sections.

\section{REFERENCES CITED}

AscenzI, A., 1955: Some Histochemical Properties of the Organic Substance in Neandertalian Bone. Am. J. Phys. Anthrop., N. S. $13: 557-566$

Bloom. W. and D. W. FAwCett, 1968: A Textbook of Histology, 9th ed., p. 225, Philadelphia-London-Toronto.

MICHAËLIS, L., 1930: Vergleichende mikroskopische Untersuchungen an rezenten, historischen und fossilen menschlichen Knochen. Veröffentl. Kriegs- und Konstitutionspathol., 6: 1-92.

PAINE, G., 1937: Fossilization of Bone. Am. Jour. Sc., Fifth Series, Vol. 34, No. $200:$ 148157.

Sergi, S., A. Ascenzi and E. Bonucci, 1972: Torus palatinus in the Neandertal Circeo I Skull. A Histologic, Microradiographic and Electoron Microscopic Investigation. Am. J. Phys. Anthrop., 36: 189-197.

Watanabe, N., 1950a: The Preservation of Bony Substances in the Soil of Prehistoric Sites. J. Anthrop. Soc. Nippon, 61 : 67-74. (Japanese with English Summary)

- $1950 \mathrm{~b}$ : On the Possible Preservation of Bone in the Fossil-bearing Formation near Akashi. J. Anthrop. Soc. Nippon. 61: 183-190. (Japanese with English Summary)

(September 4, 1973) 
繩文時代人胃盅組織の保存性について

\section{福 島 靖 夫 \\ 東京大学理学部人類学教室}

縄文時代の遺跡と考えられる五遺跡, 宮古島, 蝦島, 姥山, 伊川津, 寄倉加ら出土した人骨から樹脂包埋に よって研磨標本を作り, 観察を行った。 寄倉以外はいずれも具塚遺跡であるが, 保存状態は各遺跡について様 々である. 全体として保存はかなり悪く, 最も保存の良いと思われる姥山についても, 骨組織本来の層板状構 造はかなり破壊されてしまっている。特に最あ保存の悪い伊川津ではわずかにハヴァース管むしくはフォルク マン管と思われる構造が 見られるのみで，偏光顕微鏡下でも膠原線維による複屈折像はほとんど 観察できな い，又，寄倉出土人骨の内，佬けた骨には特に層板状構造が良く保存されているようだが，膠原線維はそれ程 残っていない. 